\title{
Assessment of Heavy Metal Levels of Agodi Reservoir in Ibadan, Nigeria
}

\author{
OGUNGBILE, PO; *AKANDE, JA; OGUNBODE, TO; ODEKUNLE, $O$ \\ Department of Environmental Management and Control, Bowen University, PMB 284, Iwo, Nigeria. \\ *Corresponding Author Email: ogungbilepeter@yahoo.com
}

\begin{abstract}
The quality of water discharged into Agodi Reservoir was determined by the levels of $\mathrm{Cd}, \mathrm{Co}, \mathrm{Cr}, \mathrm{Cu}$, $\mathrm{Fe}, \mathrm{Mn}, \mathrm{Ni}, \mathrm{Pb}$ and $\mathrm{Zn}$. Water samples were collected from the inlet, centre and outlet locations of the reservoir and their heavy metal contents were determined by standard methods using Atomic Absorption Spectrophotometer (AAS) over a period of twelve (12) months covering both rainy and dry seasons. Test location differences and seasonal variations were examined using ANOVA at $\mathrm{P}<0.05$ to establish any gradient effect associated with pollution dynamics. Results showed no seasonal variations in all the heavy metals except for Co. Also, there is no significant variation in heavy metal concentration between the test locations. The heavy metal profile in Agodi Reservoir, measured in mg/L, was as follows: $\mathrm{Mn}(64.81)>\mathrm{Fe}(43.75)>\mathrm{Zn}(23.13)>\mathrm{Cu}(12.44)>\mathrm{Co}(0.19)>\mathrm{Ni}(0.17)>\mathrm{Cd}(0.12)$. Concentrations of $\mathrm{Cr}$ and $\mathrm{Pb}$ were below detectable level. Compared to WHO recommended limits, Co fell below while others were higher than thresholds. It is concluded that Agodi Reservoir water has a potential environmental hazard unless treated before use.
\end{abstract}

\section{DOI: https://dx.doi.org/10.4314/jasem.v23i11.10}

Copyright: Copyright (C) 2019 Ogungbile et al. This is an open access article distributed under the Creative Commons Attribution License (CCL), which permits unrestricted use, distribution, and reproduction in any medium, provided the original work is properly cited.

Dates: Received: 07 October 2019; Revised: 11 November 2019; 24 November 2019

Keywords: Agodi Reservoir, heavy metals, pollution, seasonal variation.

Pollution of water is one of the most serious environmental problems. Water is regarded as polluted when changes in its quality or composition either naturally or as a result of human activities such that it becomes less suitable for drinking, domestic, agricultural, industrial, recreational, wildlife and other uses for which it should have been suitable for in its natural or unmodified state (Goel, 2006). When sewages and solid wastes are deposited in water, heavy metal toxicity can be expected. Heavy metal pollution is caused by toxic heavy metal contaminants (Bose and Hamantarja, 2005). In recent years, there has been an increasing ecological and global health concern associated with environmental contamination by heavy metals. Pollution of heavy metals in aquatic environment is a growing problem worldwide and currently have reached alarming rate (Naziret al. 2015). Major environmental contaminations and impact result from anthropogenic activity such as mining and smelting, industrial production and use, domestic and agricultural use of metals and their compounds (Shellariet al. 1998, Harawatiet al. 2000). Environmental pollution can also occur through metal corrosion, atmospheric deposition, soil erosion of metals ions and leaching of heavy metal (Goyer, 2001, $\mathrm{He}$ et al. 2005). Natural phenomena such as weathering and volcanic eruptions have also been implicated Shellariet al. 1998; He et al. 2005) reported that some heavy metals also occur naturally in the earth crust and may enter into aquatic system through human activities. Heavy metals are non-degradable, they are continuously being deposited and incorporated in water thus causing heavy metal pollution in water bodies. The present work aimed to investigate the pollutants levels of some heavy metals (Cadmium, Cobalt, Chromium, Copper, Iron, Manganese, Nickel, Lead, and Zinc) in the water in Agodi Reservoir, in Ibadan and hence the safety levels of the water for human consumption.

\section{MATERIAL AND METHODS}

The study Area: Agodi Reservoir is situated in Ibadan Oyo State, Nigeria. The latitude and longitude coordinate of Ibadan are: 7.401,962, 3.917,313. Ibadan is one of the largest cities in Nigeria. Agodi reservoir is human created reservoir formed along the path of Ogunpa River. The reservoir was constructed in the 1980s following the great flood in 1980 in Ibadan. The purpose of the construction was to serve as retention basin for excess run-off from upper section of Ogunpa River to prevent flooding downstream of the river. The reservoir covers an area of about 5.2 hectares, stretching about $1 \mathrm{~km}$ with a maximum depth of about $5 \mathrm{~m}$. The river traverses major parts of Ibadan city where it flows across many markets, eateries, schools, residential areas abattoirs mechanic workshops, parking lots waste dumps and other areas where waste are generated before discharging into Agodi Reservoir.

*Corresponding Author Email: ogungbilepeter@yahoo.com 
Sampling Regime and Sample Collection: Samples of water were collected at different points (figure 1). In the reservoir, water samples were collected from three sampling locations comprising the inlet $(F)$ centre $(G)$ and outlet $(\mathrm{H})$ parts of Agodi Reservoir. The samples were carefully labeled and taken to the laboratory to assess their heavy metal quality. The procedure employed demand immediate acidification with $5 \mathrm{ml}$ cone $\mathrm{HNO}_{3}$ and transport to laboratory for digestion which was done within 24 hours. All samples for metal analysis were stored in the refrigerator set at $4^{\circ} \mathrm{C}$ to inactivate any bacteria and prevent change in volume due evaporation.
Sample Digestion: A $50 \mathrm{ml}$ of water sample was transferred into Teflon beaker and $5 \mathrm{ml}$ of concentrated $\mathrm{HNO}_{3}$ was added. This was followed by gentle boiling on a hot plate in a fume cupboard for about 45 minutes. The digested samples were quantitatively transferred into a $25 \mathrm{ml}$ volume metric flask and diluted with distilled water.

Metal analysis: The digest samples were analyzed for heavy metal $(\mathrm{Cd}, \mathrm{Co}, \mathrm{Cr}, \mathrm{Cu}, \mathrm{Fe}, \mathrm{Mn}, \mathrm{Ni}, \mathrm{Pb}$ and $\mathrm{Zn}$ ) using Atomic Absorption Spectrophotometer (Buck 200 AAS model). The instrument setting and operational conditions were done in accordance with the manufacturers' specifications.

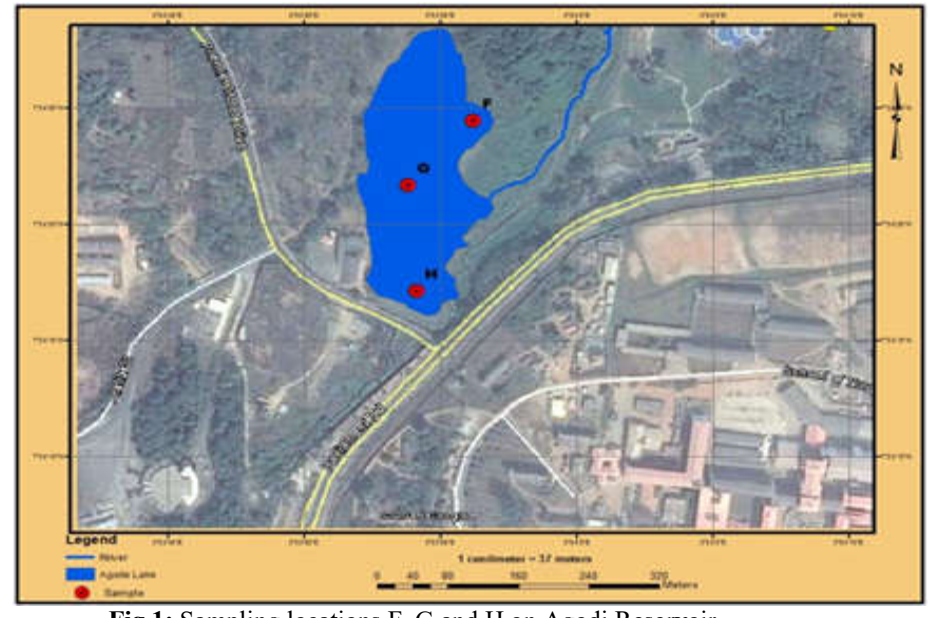

Fig 1: Sampling locations F, G and $\mathrm{H}$ on Agodi Reservoir

Statistical Data Analysis: The statistical data analyses were measured on means, Correlation Coefficients and Linear regression supported by ANOVA. A combination of Microsoft Excel and R-Statistics were employed.

\section{RESULTS AND DISCUSSION}

The results of analysis of heavy metals for each location from each steps of the methodology is presented below. The results are presented in Tables 1 , 2 and 3. Table 1 represents the mean of the concentrations of metals in different water samples. Table 2 and 3 are values of heavy metals at different seasons. The major stream entering Agodi Reservoir is Ogunpa River, which serves as a point source of pollution to the reservoir. Ogunpa River travels long distance through residential areas of New and Old Bodija and collects a variety of wastes from open drains, industries, slaughter and other sources, before discharging into Agodi reservoir. The waste contains pollutants which are of both organic and inorganic origin, some of the pollutants which may be biodegradable or non-biodegradable. The impurities include agricultural wastes and nutrients which may be oxygen demanding, also heavy metals and toxic substances that pollute the Reservoir. Non-point sources of pollution to Agodi Reservoir are run-offs from Agodi Parks and gardens in the city, agricultural areas, construction sites, roads and streets, which are secondary grounds arising from environmental degrade. Increasing complex due to increase in human population which subsequently results into rapid urbanization along the water body contributes significantly to the pollution of the reservoir. Heavy metal pollution of Agodi Reservoir can therefore be traced to both natural and anthropogenic sources. Eroded earth crust is a natural source of heavy metal that percolate into and sediment whereas humaninfluenced source heavy metal contamination could be from vehicular gas exhaust, laundry discharges, engine disposal and fertilizer use.

Heavy Metals Concentrations: The concentration of $\mathrm{Cd}$ in the water body averaged $0.12 \mathrm{mg} / \mathrm{L}$ during the experimental year. Analysis of variance (ANOVA) of cadmium data showed no significant difference $(\mathrm{P}$ 
$<0.05)$ at all the locations which imply no gradient effect. The mean concentration of cadmium in dry season was $0.06 \mathrm{mg} / \mathrm{L}$ and in wet season was $0.17 \mathrm{mg} / \mathrm{L}$. The T-test statistics at $95 \%$ C.I. showed no significant difference between the dry and wet season. A linear regression of $\mathrm{Cd}$ in the water body along the sample locations gave a negative correlation $\left(r^{2}=2 \%\right)$

The mean concentration of cobalt was $0.19 \mathrm{mg} / \mathrm{L}$ in the water body during the experimental year. Mean concentration of cobalt in dry season was $0.37 \mathrm{mg} / \mathrm{L}$ and in wet season was below detectable level. The Ttest statistics at $95 \%$ C.I. showed significant difference between the dry and wet seasons. Analysis of variance along locations of cobalt data showed no significant difference $(\mathrm{P}<0.05)$. A linear regression of $\mathrm{Co}$ in the water body along the sample locations gave a weak negative correlation $\left(r^{2}=5 \%\right)$

\begin{tabular}{|c|c|c|c|c|c|}
\hline \multirow{2}{*}{ Heavy metals in $\mathrm{mg} / \mathrm{L}^{-1}$} & \multicolumn{3}{|c|}{ Locations } & \multirow{2}{*}{ Mean } & \multirow{2}{*}{ WHO Standards } \\
\hline & $\mathrm{F}$ & $\mathrm{G}$ & $\mathrm{H}$ & & \\
\hline $\mathrm{Cd}$ & 0.10 & 0.19 & 0.06 & 0.12 & 0.005 \\
\hline $\mathrm{Co}$ & 0.16 & 0.44 & 0.01 & 0.19 & 5.0 \\
\hline $\mathrm{Cr}$ & BDL & BDL & BDL & 0.00 & 0.05 \\
\hline $\mathrm{Cu}$ & 10.44 & 8.05 & 18.70 & 12.44 & 1.0 \\
\hline $\mathrm{Fe}$ & 21.59 & 58.58 & 51.07 & 43.75 & 0.1 \\
\hline $\mathrm{Mn}$ & 1.10 & 38.35 & 154.99 & 64.81 & 0.5 \\
\hline $\mathrm{Ni}$ & 0.19 & 0.32 & BDL & 0.17 & 0.02 \\
\hline $\mathrm{Pb}$ & BDL & BDL & BDL & 0.00 & 0.05 \\
\hline $\mathrm{Zn}$ & 20.33 & 12.97 & 36.07 & 23.13 & 5.0 \\
\hline
\end{tabular}

Table 2: Heavy metals concentrations in water along Agodi River during dry Season

\begin{tabular}{|c|c|c|c|c|}
\hline \multirow{3}{*}{$\begin{array}{l}\text { Heavy metals } \\
\text { in } \mathrm{mg} / \mathrm{L}^{-1}\end{array}$} & \multicolumn{3}{|c|}{ Dry Season } & \multirow{3}{*}{${ }^{* *}$ Mean } \\
\hline & \multicolumn{3}{|c|}{ Agodi Reservoir } & \\
\hline & $\mathrm{F}$ & $\mathrm{G}$ & $\mathrm{H}$ & \\
\hline $\mathrm{Cd}$ & 0.11 & BDL & 0.07 & 0.06 \\
\hline Co & 0.23 & 0.88 & 0.01 & 0.37 \\
\hline $\mathrm{Cr}$ & BDL & BDL & $\mathrm{BDL}$ & 0.00 \\
\hline $\mathrm{Cu}$ & 5.71 & 5.63 & 34.21 & 15.18 \\
\hline $\mathrm{Fe}$ & BDL & 12.69 & 75 & 29.23 \\
\hline $\mathrm{Mn}$ & 0.94 & 2.25 & 307.81 & 103.67 \\
\hline $\mathrm{Ni}$ & BDL & 0.54 & BDL & 0.18 \\
\hline $\mathrm{Pb}$ & BDL & BDL & BDL & 0.00 \\
\hline $\mathrm{Zn}$ & 34.92 & 6.62 & 65.23 & 35.59 \\
\hline
\end{tabular}

$\mathrm{BDL}=$ Below Detectable level

Table 3: Heavy metals data in water along Agodi River during wet season

\begin{tabular}{lllll}
\hline Heavy metals & \multicolumn{5}{c}{ Wet Season } \\
ing/L $\mathrm{L}^{-1}$ & $\mathrm{~F}$ & $\mathrm{G}$ & ${ }^{* *}$ Mean \\
$\mathrm{Cd}$ & 0.08 & 0.38 & 0.05 & 0.17 \\
$\mathrm{Co}$ & $\mathrm{BDL}$ & $\mathrm{BDL}$ & 0.01 & 0.00 \\
$\mathrm{Cr}$ & 0.01 & 0.01 & 0.01 & 0.01 \\
$\mathrm{Cu}$ & 15.17 & 10.47 & 3.18 & 9.61 \\
$\mathrm{Fe}$ & 43.17 & 104.47 & 27.13 & 58.26 \\
$\mathrm{Mn}$ & 1.25 & 74.44 & 2.16 & 25.95 \\
$\mathrm{Ni}$ & 0.38 & 0.09 & 0.01 & 0.16 \\
$\mathrm{~Pb}$ & 0.01 & 0.01 & 0.01 & 0.01 \\
$\mathrm{Zn}$ & 5.74 & 19.32 & 6.91 & 10.66 \\
\hline \multicolumn{5}{c}{}
\end{tabular}

The mean concentration of chromium in the water body was below detectable level the mean $\mathrm{Cr}$ value during the dry season was below detectable level while the mean value for the wet season was $0.01 \mathrm{mg} / \mathrm{L}$. Ttest statistics at 95\% C.I showed no significant difference in the two seasons. Also, one-way analysis of variance ( $\mathrm{F}$-statics) at $\mathrm{P}<0.05$ showed no significant difference at the various locations which implies no gradient effect.

Copper concentration in the water body averaged $12.44 \mathrm{mg} / \mathrm{L}$. The mean copper value during the dry season was $15.18 \mathrm{mg} / \mathrm{L}$ while during wet season was $9.61 \mathrm{mg} / \mathrm{L}$. T-test statistic at $95 \%$ C.I showed no significant difference in the two seasons. One-way 
analysis of variance (F-statistic) at $\mathrm{P}<0.05$ showed no significant difference in values between the test locations. A linear regression of $\mathrm{Cu}$ in the water body along the sample location showed a positive weak correlation $\left(r^{2}=10 \%\right)$

Iron concentration in the water body averaged $43.75 \mathrm{mg} / \mathrm{L}$. The mean values of Iron in dry season and wet seasons were $29.23 \mathrm{mg} / \mathrm{L}$ and $58.26 \mathrm{mg} / \mathrm{L}$ respectively. T-test statistic at $95 \%$ C.I showed no significant difference in the two seasons. One-way analysis of variance (F-statistic) at $\mathrm{P}<0.05$ showed no significant difference in values between the test locations. A linear regression of $\mathrm{Fe}$ in the water body along the sample locations showed weak positive correlation $\left(\mathrm{r}^{2}=7 \%\right)$

The mean concentration of Manganese in the water body during the test period was $64.81 \mathrm{mg} / \mathrm{L}$. The means values of Manganese in dry and wet seasons were $103.67 \mathrm{mg} / \mathrm{L}$ and $25.95 \mathrm{mg} / \mathrm{L}$ respectively. T-test statistic at $95 \%$ C.I showed no significant difference in the two seasons. One-way analysis of variance (Fstatistic) at $\mathrm{P}<0.05$ showed no significant difference in values between the test locations. A linear regression of $\mathrm{Mn}$ in the water body along the sample locations a strong positive correlation $\left(\mathrm{r}^{2}=100 \%\right)$

Nickel concentrations in the waters averaged $0.17 \mathrm{mg} / \mathrm{L}$ during the test period. One way analysis of variance (F-statistics) at $\mathrm{P}<0.05$ showed no significant difference in values between the test locations. The mean values of Nickel in dry and wet seasons were $0.18 \mathrm{mg} / \mathrm{L}$ and $0.16 \mathrm{mg} / \mathrm{L}$ respectively. T-test statistics at $95 \%$ C.I showed no significant difference in the two seasons. A linear regression of $\mathrm{Ni}$ in the water bodies along the sampling locations, showed strong negative correlation $\left(r^{2}=77 \%\right)$

The concentration of $\mathrm{Pb}$ in the waters was below detectable level. One-way analysis of variance (Fstatistics) at $\mathrm{P}<0.05$ showed no significance at the test locations. T-test statistic at $95 \%$ C.I. showed no significant difference seasonally. No relationship was established in the levels of $\mathrm{Pb}$ in the water bodies along the test locations.

The mean concentration of $\mathrm{Zn}$ in the waters for the experimental period was $23.13 \mathrm{mg} / \mathrm{L}$. One-way analysis of variance (F-statistics) at $\mathrm{P}<0.05$ in all the locations showed no significant difference. The mean values of Zinc in dry season and wet seasons were $35.59 \mathrm{mg} / \mathrm{L}$ and $10.66 \mathrm{mg} / \mathrm{L}$ respectively. T-test statistic at $95 \%$ C.I showed no significant difference in the two seasons. A linear regression of $\mathrm{Zn}$ in the water body along the sample locations showed strong positive correlation $\left(\mathrm{r}^{2}=72 \%\right)$.

Cadmium is a heavy metal of considerable environmental and occupational concern. It is highly distributed in the earth's crust at an average of about $0.1 \mathrm{mg} / \mathrm{kg}$. The highest level of cadmium compounds in the environment is accumulated in sedimentary rocks and marine. Phosphates which contain $15 \mathrm{mg} / \mathrm{kg}$ (Gesmap, 1987), cadmium is a non-essential and toxic element to humans. Kidney is the critical target organ for toxicity of cadmium in humans critical effects include increases excretion of proteins in urine of proximal tabular cell damage. The severity of the effect depends on duration and magnitude of exposure. The international Agency for Research on Cancer (IARC) classified cadmium into group 1 carcinogen to humans while the US Environmental Protection Agency (EPA) have conjectured that cadmium is a probable carcinogen by inhalation. Epidemiological data from occupational settings confirm the lungs as the primary target organ.

Concentration of $\mathrm{Cd}$ level was above the recommended WHO for drinking water. The WHO maximum allowable concentration of cadmium in drinking water is $0.005 \mathrm{mg} / \mathrm{L}$ (WHO, 2011). This gives a cause for concern as the use of water high in Cd could cause adverse health effects. The mean Co level was below the maximum WHO maximum allowable concentration of Co in drinking water is $5 \mathrm{mg} / \mathrm{L}$ (WHO, 2011). Since nearly all the water samples analyzed contained Co concentration that may not be detrimental to consumers, the water may not constitute health risk due to cobalt. The values of chromium were lower than the maximum contamination level (MCL) of $0.1 \mathrm{mg} / \mathrm{L}$ recommended by USEPA 1986 and $0.05 \mathrm{mg} / \mathrm{L}$ by WHO (2011). Chromium may be present in the hexavalent (Chromate) or trivalent form, but the trivalent chromium is extremely irritating and toxic to human tissues. Chromate poisoning causes skin disorder and liver damage. Chromium is certainly an objectionable contaminant in drinking water because of its alleged carcinogenic effects (Hassan et al. 1989, Juma, 2013 and Mustafa et al. 1988). Concentration of $\mathrm{Cu}$ was above $1.0 \mathrm{mg} / \mathrm{L}$ WHO recommended level for drinking water (WHO, 2011). Copper is an essential trace nutrient that is required in small amounts (5-20) micrograms per gram $(\mu \mathrm{g} / \mathrm{g})$ by humans and other mammals, fish and shellfish for carbohydrate metabolism and the functioning of more than 30 enzymes. It is also needed for the formation of hemoglobin and haemocyanis, and the oxygen transporting pigments in the blood of vertebrates and shellfish respectively. Copper is toxic and capable of causing "Wilson disease". It has harmful biochemical 
effects and toxicity in flora, fauna and human beings. Intake of $\mathrm{Cu}$ through air, water and food beyond its permissible limits is hazardous. For example, ingestion of $15-75 \mathrm{mg}$ of $\mathrm{Cu}$ causes - intestinal disorders. Excessive intake of $\mathrm{Cu}$ may even cause hemolysis, hepatotoxie and nephron-toxic effects. Copper toxicity leads to mucosal irritation, corrosion, widespread capillary damage, hepatic and renal damage also nervous system irritation followed by depression (Krishnamurthy et al. 2009). The values of Fe obtained in this study was above $0.1 \mathrm{mg} / \mathrm{L} \mathrm{WHO}$ recommended level for Fe in drinking water (WHO, 2011), hence use of such water for domestic purposes may pose serious long-term danger. In cellular process in both plants and animals Iron is very important metal (Lovell, 1989). The major effect of Iron in water is aesthetic. High concentration of Iron above $0.3 \mathrm{mg} / \mathrm{L}$ in water gives rise to consumer complaints due to its ability to discolour aerobic water (WHO, 2004).

The WHO maximum allowable concentration of Mn in drinking water is $0.5 \mathrm{mg} / \mathrm{L}$ (WHO, 1993). It was, however observed that the water contained concentrations higher than above stated WHO limit. This gives a cause of concern as the use of water high in Mn could cause adverse health effects such as lung, liver and vascular disturbances, reduces blood pressure, developmental problems in animal foetus, brain damage, irritation to the eye (Goyer, 1992; Gossel, 1994, Copeland, 1996). On the other hand Mn is an element of low toxicity having considerable biological significance and one of the more biogeochemical and active transition metals in aquatic environment (Evans et al. 1977). The concentration of Nickel in the water body is higher than the $0.02 \mathrm{mg} / \mathrm{L}$ recommended WHO maximum allowable concentration for drinking water (WHO, 1993). Hence the use of such water for domestic purposes may pose danger.

Nickel is nutritionally essential trace metal for at least several animal species, micro-organisms and plant, and therefore either deficiency or toxicity symptoms can occur, respectively too little or too much Nickel is taken up (Bencko, 1983; Scott-Fordsmand, 1997). Nickel is however ubiquitous, frequently responsible for allergic skin reactions and it has been implicated as common causes of allergic contact dermatitis, confirmed through positive dermal patch test (Kitauraet al. 2003; Clarkson, 1988, Iris, 1996). The sensitivity to nickel would emphasize the need to monitor nickel content in drinking water and nickelallergic subjects should be sensitive to increase absorption when drinking water on an empty stomach (Nelson et al. 1999)
The recommended $\mathrm{WHO}$ value for $\mathrm{Pb}$ in drinking water is $0.005 \mathrm{mg} / \mathrm{L}$ (WHO, 2011). The study showed that the concentrations were lower than the WHO recommended standard. The concentrations of $\mathrm{Pb}$ in the dry season were low and could not be detected in water from all the sampling locations. Lead has been potentially hazardous and toxic to most forms of life by the United States Environmental Protection Agency (US EPA, 1986). Some of the health hazards of $\mathrm{Pb}$ are chronic neurological disorders in foetus and in children when the concentration exceeds $0.1 \mathrm{mg} / \mathrm{L}$.

The values of Zinc obtained in this study were higher than the $5.0 \mathrm{mg} / \mathrm{L}$ WHO recommended level of Zinc in drinking water (WHO, 1984, 2011). The high level of Zinc in this water body could be as a result of refuse dump and domestic sewage sources around the water body. The concentrations of Zinc could also be attributed to industrial effluent discharge inside the water. It has been found that high concentration of $\mathrm{Zn}$ could be toxic to fish and some other aquatic organisms (Alabaster and Llyods 1982). Low toxicity level of $\mathrm{Zn}$ has no effect on man, however prolonged accumulation of large doses can cause some health effects which may include fatigue, dizziness and neutropenia (Hess and Schmid, 2002).

Conclusions: Heavy metal $(\mathrm{Cd}, \mathrm{Cu}, \mathrm{Fe}, \mathrm{Mn}, \mathrm{Ni}$ and $\mathrm{Zn}$ ) content in Agodi reservoir were higher than the WHO recommended values for drinking water. The water was highly polluted with these heavy metals and therefore not recommended for human consumption. Seasonal variation using T-test statistic showed no significant differences in all the heavy metals except for Co. There were no significant differences in all the heavy metals at the various sampling locations, implying no gradient effect. The type and sources of water discharged into the Agodi Reservoir is implicated for intense pollution of the water. A monitoring network is needed to effect preventive actions and reduce anthropogenic discharges into the reservoir.

\section{REFERENCES}

Alabaster, JS; Llyods, R (1982).Water criteria for freshwater fish, $2^{\text {nd }}$ edition Butterworths Publication London, p. 361.

Bencko, V (1983). Nickel: A review and environmental toxicology. J. Hyg. Epidem. Micro. Imnim 27, 237.

Bose B; Hamantarajan, A (2005).Developments in Physiology, Biochemistry and Molecular Biology of Plants. New Delhi India: New India Publishing Agency, p.105 
Clarkson, TW (1988). Biological Monitoring of Toxic Metals. Plenum Press New York, pp. 265-282.

Copeland, KR (1996). Trace elements in chemical clinical chemistry, $3^{\text {rd }}$ edition. Lysons K.P. (eds) Lippincott New York, pp.118-136.

Evans, DW; Cutshall, NH; Cross, FH; Wolfe, DA (1977).Manganese cycling in the Newport estuary, North California. Estuar. Coast Marine Sci. 5. 71-80.

Gasmap, P (1987). Joint Group of Exports on Scientific Aspects of Marine Pollution. Report of the seventeenth session. Geneva, Switzerland; World Health Organization, p.48

Goel, PK (2006). Water Pollution cause, effects and control second Revised Edition New Age International Publishers, p. 418

Gossel, TA; Bricker, TD (1994). Principles of Chemical Toxicology. Raven Press New York, pp86-112.

Goyer, RA (2001). Toxic Effects of Metals In: Klassen CD (ed) Cassarella and Doulls Toxicology the basic science of poisons McGraw Hill New York NY, pp 711-723.

Goyer, RA (1992).Toxic effects of metals, Toxicology $4^{\text {th }}$ edition. Amodu, M.O., Doull, J. Klassen C.D (eds) Pergamon Press, pp. 811-867

Harawati N; Suzuli, S; Hayashi, K; Riva, JF; Rogonna H (2000). Cadmium, Copper and Zinc levels in rice and soils of Japan, Indonesia and China by soil type. Bull Environ. Contam. Toxicol. 64:3539.

Hassan, M.A; Hanaa, T; Mustafa, T; Rihn, I (1989). Lead and chromium concentration in portable water of the Eastern Province of Saudi Arabia. Bul. Environ. Contam. Toxicol. 43(4): 529-533.

He, ZI; Yang, XE; Stofella, PJ (2005). Trace elements in agro-ecosystems and impact on environment. $J$. Trace Elimination. Medical Biol. 10: 125-140.

Hess, R; Schmid, B (2002). Zinc Supplement overdose can have toxic effects. J. Paediatr. Haemato. Oncol. 24: 582-584.

IRIS, (1996). Nickel soluble salts Web site http://www.cpa.gov/iris/subst/0271.htm Accessed 06/07/2005.
Juma, M (2013). Trace elements and carcinogenicity: a subject review. Biotech 3(2): 85-96.

Kitaura, H; Nakao, N; Yoshida, N; Yamadi, T (2003). Induced sensitization to nickel in guinea pigs immunized with mycobacteria by injection of purified protein derivative with nickel New Microbio. 26(1): 101.

Krishnamurthy, A.J; Moore, N; Mahowald, W; Chao Luo, SC; Doney, K; Lindsay, Zender, CS (2009). Impacts of increasing anthropogenic soluble iron and nitrogen deposition on ocean biogeochemistry, Global Geochemical cycles 23: $1-15$.

Lovell, RT (1989). Nutrition and feeding of fish. Published by Van Nostrand Reinhold New York, pp. 260.

Mustafa, HT; Hassan, HMA; Abo Melha, A; Talat, I (1988).Cadmium and Zinc concentrations in portable water of the Eastern Prince of Saudi Arabia. Bull. Environ. Contam. Toxicol.40: 462467.

Nazir, R; Khan, M; Nasab, M; Ur Rehan, HM; Ur Rauf, N; Shahab, S; Amer, N; Sajed, M; Ullah, M; Rafeeq, M; Shaheen, Z (2015). Accumulation of Heavy Metals ( $\mathrm{Ni}, \mathrm{Cu}, \mathrm{Cd}, \mathrm{Cr}, \mathrm{Pb}, \mathrm{Zn}, \mathrm{Fe})$ in the soil, water and plants and analysis physicchemical parameters of soil and water collected from Tanda Dam Kohar J. Pharmacological Sci. Res. 7(3) 89-97.

Nelson, G.D; Soderberg, U; Jorgensen, P.J; Ternpleton, DM; Rosmussen, SN; Andersen, KE; Grandjean, P (1999).Absorption and retention of nickel from drinking water in relation to food intake and nickel sensitivity. Toxic. Applic. Pharmacol. 154, 67.

Scott-Fordsmand, JJ (1997). Toxicity of nickel to soil organisms in Denmark. Rev. Environ. Contam. Toxicol. 148:1-34.

Shellari, S; Schwart, C; Hasko, A; Morel, JL (1998).Heavy Metals in Soils and Plants of Serpentine and Industrial sites of Albanlascri. Total. Environ. 209:133-142.

United States Environmental Protection Agency (US EPA) (1986). Quality Criteria for Water United States Environmental Protection Agency Office of Water Regulations and Standards DC 20460. 
World Health Organization WHO (2004).Guidelines for drinking water quality $3^{\text {rd }}$ edition. World Health Organization, Geneva.

World Health Organization WHO (2008).Guidelines for Drinking-water Quality $3^{\text {rd }}$ Ed. (1) Recommendations. World Health Organization, Geneva 2008.
World Health Organization WHO (2011).World Health Organization. Guidelines for Drinking Water Quality, $4^{\text {th }}$ Edition Geneva, Switzerland.

World Health Organization WHO (1993).Guidelines for Drinking Water $2^{\text {nd }}$ Edition (1) Recommendations WHO, Geneva 1993.ISBN 92, 4. 154460 . 